\title{
Ethnic Hatred and Universal Benevolence: Ethnicity and Loyalty in Precolonial Myanmar, and Britain
}

\author{
VICTOR LIEBERMAN \\ History, University of Michigan, Ann Arbor, MI, USA
}

The political function of ethnicity in the premodern world is a topic of some debate and uncertainty. The so-called "modernist" school insists that the development of ethnically based nationalism in the eighteenth century was a radically transformative development that distinguished Western Europe from the rest of Eurasia and from Europe itself in earlier centuries. ${ }^{1}$ By contrast, the so-called "perennialist" school argues that ethnicity served essentially the same psychological and political function before and after ca. 1750 , that "nationalism" is an equally valid term in both periods, and indeed, to quote one recent partisan of this view, "that nations and national states have existed since the beginning of statehood millennia ago." 2

Debate therefore centers on two intertwined questions: By what criteria should we periodize political community across Eurasia? To what extent did

Acknowledgments: The author wishes to thank Professor Michael J. Braddick and the anonymous $\mathrm{CSSH}$ readers for their insightful comments on an earlier draft of this paper.

1 Benedict Anderson, Imagined Communities: Reflections on the Origin and Spread of Nationalism, rev. ed. (London, 1991); John Breuilly, "Changes in the Political Uses of the Nation," in Len Scales and Oliver Zimmer, eds., Power and the Nation in European History (Cambridge, 2005), 67-101; idem, Nationalism and the State, 2d ed. (Chicago, 1993), chs. 1-3; Eric J. Hobsbawm, Nations and Nationalism since 1780 (Cambridge, 1992); John Breuilly, ed., The Oxford Handbook of the History of Nationalism (Oxford, 2013).

2 Azart Gat, Nations: The Long History and Deep Roots of Political Ethnicity and Nationalism (Cambridge, 2013), frontispiece; Aviel Roshwald, The Endurance of Nationalism: Ancient Roots and Modern Dilemmas (Cambridge, 2006); Anthony D. Smith, Ethno-Symbolism and Nationalism: A Cultural Approach (London, 2009); Adrian Hastings, The Construction of Nationhood: Ethnicity, Religion and Nationalism (Cambridge, 1997); Colette Beaune, The Birth of an Ideology: Myths and Symbols of Nation in Late-Medieval France (Berkeley, 1991); Rainer Babel and Jean-Marie Moeglin, eds., Identite Regionale et Conscience Nationale en France et en Allemagne du Moyen Age a l'Epoque Moderne (Sigmaringen, 1997). See, too, the sympathetic and sophisticated analysis of "perennialist" thought in Rogers Brubaker, Ethnicity without Groups (Cambridge, Mass., 2004), 83-87. 
eighteenth-century nationalism constitute a radical innovation, and to what extent a mere variation on established patterns?

I address these issues by deploying the term "political ethnicity" to describe what I argue were generally similar concepts of community in restricted sectors of Asia from the eleventh century to the late nineteenth century, and in much of Europe from the eleventh century to the early or mid-eighteenth century. To focus a potentially overbroad discussion I use Myanmar (formerly Burma) and England/Britain as case studies. The appeal of these particular realms derives from their comparable size, population, and regional influence at the beginning of our period; from unexpected parallels in their political dynamics, trajectories, and chronologies over several centuries; and from the novel insights into Eurasia as a coherent ecumene that derive from comparing the future colony and the future colonizer, a Buddhist society and a Christian society, at the farthest ends of Eurasia.

Political ethnicity I define as a complex of traits specific to a named population whose distinctiveness was recognized by group members and outsiders alike. Ethnic features became political when one or more elements were used to identify leaders and followers as members of a state-centered collectivity eager to secure resources in competition with other groups. Insofar as ethnic traits could be acquired, ethnic identity was mutable. But in some societies, it was said to be racial, a matter of family descent.

Political ethnicity in precolonial Myanmar, premodern Britain, and other countries located around what I term the Eurasian rimlands (a term to be discussed shortly) differed from nationalism in these respects: (a) Political ethnicity located sovereignty not in the population, but in the ruler and his dynasty, whose authority in turn derived from God or cosmic law. (b) In lieu of legal/civic equality, political ethnicity posited radical social hierarchy. There were no generic "citizens." (c) Whereas nationalism focused loyalty on a community intermediate between the local and the global, political ethnicity directed ultimate loyalty to a religion or philosophical tradition (Buddhism, Christianity, Confucianism, etc.), whose intended beneficiaries were humanity itself. Ethnic claims to preeminence often invoked superior commitment to doctrinal truth. (d) Systematically promoted in schools and state institutions, patriotism acquired a quasi-permanent public character. But expressions of political ethnicity - galvanized by external threats and reliant on personal or religious networks - tended to be far more episodic and shortlived. (e) Nation-states expected residents to conform to a cultural template, but states supporting political ethnicity typically welcomed ethnic minorities without requiring assimilation. Political clienteles therefore often were multiethnic. (f) Likewise, dynastic considerations led premodern states, unlike nation-states, to acquire (and in Europe, to exchange) territories without regard to local culture. Accordingly, boundaries were fluid, rather 
than fixed. In all these ways the modernist distinction between nationalism and all previous forms is valid.

But political ethnicity and nationalism also shared a number of features. Both systems identified the state with a particular ethnicity-English, French, Spanish, Russian, Myanmar, Vietnamese, et cetera - and assumed that the leaders of the state (if not necessarily the dynasty itself) and the bulk of its subjects belonged to that ethnicity, embodied in a common ethnonym. Drawing a circle around ethnic communities, nationalism, and political ethnicity both elevated particular artifacts-language, religious practices, body adornment - as badges of inclusion. From the medieval era to the nineteenth century, in Southeast Asian and key European realms we therefore find evolving but recognizable continuities in regnal self-image and ethnic symbolism. ${ }^{3}$ Nationalism was unprecedentedly ambitious, systematic, and discursively intolerant, but in this perspective it also can be seen as a hypertrophic elaboration and logical extension of political ethnicity.

Most basic perhaps, at a reasonable level of abstraction similar dynamics propelled political ethnicity in Southeast Asia and other Asian rimlands to ca. 1850, political ethnicity in Europe to 1700/1750, and nationalism in Europe after 1750. In each location agrarian and demographic expansion joined commercial specialization to knit together hitherto disparate communities; to encourage the circulation of texts, people, and commodities; and to promote the founding of monasteries and schools and a corresponding expansion in literacy. In these ways, gradually or fitfully, consciously or unconsciously, overarching ethnic norms penetrated encapsulated local cultures. Because political capitals invariably were located in economically privileged cores, commercial expansion enhanced the ability of each capital, whether dynastic or national, to standardize and impose ethnic/cultural norms on provincial centers. At the same time, across both Southeast Asia and Europe state strengthening increased the frequency, scale, and emotional costs of warfare, spurring in-group/out-group stereotypes and popular identification with the throne as protector and beacon. Between ca. 1100 and 1850 Eurasian climate and expanding long-distance trade ensured that cycles of economic expansion and retardation, state-strengthening and temporary collapse, and cultural integration correlated remarkably well in Southeast Asia and Western Europe. In both Southeast Asian and European polities, we thus see a notable acceleration of ethnic standardization after 1650/1700.

Political ethnicity in Southeast Asia and Europe and nationalism in Europe resembled one another in another basic respect: all such movements could develop only in what I referred to as the Eurasian rimlands. In that vast exposed zone of Eurasia subject to Turkic, Mongol, or Manchu occupation,

3 Cf. Smith, Ethno-Symbolism. 
political ethnicity such as we find in Myanmar and Britain was impossible because (a) open terrain and Inner Asian military strength favored the incorporation into a single empire of extraordinarily diverse and far-flung cultures, and (b) Inner Asian elites themselves did not share ethnicity with their subjects and indeed frequently sought to maintain ethnic distinction as the sine qua non for preserving political power. The universal empires of Yuan and Qing China, Mughal India, and the Ottomans therefore were inherently hostile to political ethnicity. But in those parts of Eurasia where mountains, island or peninsular locations, inadequate grasslands, or insalubrious climate protected against Inner Asian conquest-in particular, around the continental perimeters - the basic Burmese and British pattern appeared. Conditions were especially favorable in kingdoms of modest territorial and demographic scale with readily defensible frontiers. ${ }^{4}$ Thus, between 1500 and 1850 not only in several West European realms but also in Russia, Japan, Korea, Myanmar, Siam, Vietnam, and Sri Lanka the core ethnicity grew more dominant, uniform, and politically salient. And yet to repeat, ethnicity normally remained subordinate to, or camouflaged by, religious systems, and royal clienteles often remained multiethnic. This was true not only in Asia, but in most of Western Europe until the seventeenth or eighteenth centuries.

If through the eighteenth century protected rimlands in both Europe and Asia supported political ethnicity, how then do we answer the basic question: why only in northwest Europe did it evolve into what we now recognize as nationalism - and its later offspring, democracy? The answer, I shall argue, was two-fold. First, in England, France, Sweden, et cetera, medieval legal traditions and European religious culture favored unique institutions of corporate representation, along with a closer tie between territory and peoplehood than we find in most Asian realms, including the Asian rimlands. Second, in Western Europe after ca. 1700 incomparably rapid economic growth, symptom and cause of Europe's unfolding global commercial hegemony, promoted nationalism by revolutionizing fiscal structures, accelerating cultural standardization, radically broadening the political base, and subjecting religious tradition to rationalist critiques. In degree if not in kind, these changes had no parallel in the Asian rimlands, or indeed in Asia at large.

\footnotetext{
${ }^{4}$ China defies the link between political ethnicity and geographic compactness because integrative cultural instruments - an official language above myriad local dialects, an ideographic rather than alphabetic script, and a standard examination literary corpus - generated an effective, if elitist political ethnicity under the Song and Ming dynasties when China proper was free from Inner Asian control. Russia, however, is less of an exception to the link between ethnicity and modest scale than one may think because Russia's population was of the same magnitude as that of West European kingdoms, and was heavily concentrated in a relatively small southwestern sector of the empire.
} 
Documenting these claims requires a book-length study, ${ }^{5}$ and the present essay attempts merely a preliminary overview. On the assumptions that (a) Burmese history and the dynamics of political ethnicity in general are unfamiliar to most readers, and (b) Myanmar was loosely representative of Asian rimlands, I begin by describing the development of political ethnicity in Myanmar ca. 1050-1850. I then proceed to consider political ethnicity in the British Isles and the routes by which that phenomenon evolved into English/British nationalism.

\section{ETHNICITY AND CULTURE IN THE PAGAN EMPIRE TO CA. 1300}

Pagan, which flourished from ca. 1050 to 1300 , was the first polity to control extensive sectors of western Mainland Southeast Asia. ${ }^{6}$ Although or because its unification of the Irrawaddy basin and a highland fringe was unprecedented, the empire was deeply segmented-administratively, socially, and ethnically. Direct royal authority was confined to the capital region, the chief ricegrowing area, while major centers elsewhere in the basin were entrusted to royal relatives, senior officials, or powerful local families. An 1196-1198 inscription describing King Nara-pati-si-thu's empire suggests that it was seen not as a stable, unitary entity, but rather as an ad hoc collection of individual lands assembled through the king's personal prowess. ${ }^{7}$

Burmese-speakers apparently entered the agriculturally favored northern sector of the Irrawaddy basin, Upper Myanmar, from adjacent uplands only in the ninth century, and it was in the north that Burmese-speakers long remained concentrated. A 1235 inscription referred to Upper Myanmar as the "Burmese country"-myan-ma pyei. ${ }^{8}$ That this was indeed an area of Burmese cultural hegemony is suggested by the thirteenth-century westward expansion of Burmese ethnicity from the heartland of settlement and by the fact that some non-Burmese deportees to Upper Myanmar adopted Burmese names. Outside Upper Myanmar, however, the Irrawaddy lowlands and the vast highland interior were home to a great variety of non-Burmese languages and cultures. But even in Upper Myanmar, bondsmen, many of

5 See my Embracing the World, Hating Your Neighbors: Ethnicity and Loyalty in Europe and Asia c. 1400-1850 (Cambridge, Mass., forthcoming). Note that although Inner Asians were not a factor, several barriers to political ethnicity similar to those in Qing China, Mughal India, and the Ottoman Empire also characterized the Habsburg Empire, though not the Russian Empire.

6 On Pagan history and culture, see Gordon H. Luce, Old Burma-Early Pagan, 3 vols. (Locust Valley, NY, 1969); idem, "Note on the Peoples of Burma in the 12th-13th Century A.D.," Journal of the Burma Research Society 42 (1959): 52-74; Than Tun, Hkit-haung myan-ma ya-zawin (Rangoon, 1969); Saw Lu, Pagan-hkit myan-ma sa, 3 vols. (Rangoon, 1996); Geok Yian Goh, The Wheel Turner and His House: Kingship in a Buddhist Ecumene (De Kalb, 2015); Michael Aung-Thwin, Pagan: The Origins of Modern Burma (Honolulu, 1985).

7 Shei-haung myan-ma kyauk-sa-mya, t. 474-1150 [henceforth SHMK], 6 vols. (Rangoon, 1972-1991), I, 65-66.

8 Ibid., I, 260-62. 
them deportees, bore diverse ethnic labels (Indian, Karen, Kadu, Pyu, Shan, Lawa, Talaing, Kadu). Moreover, to judge from later patterns, among longsettled Burmese speakers themselves inter-village and interregional differences in dialect and custom were substantial.

Localism reflected in part the autarkic nature of the economy. Monetized exchange was certainly known, especially among capital elites, but agriculture remained heavily subsistence, and by post-Pagan standards market integration and the circulation of material and cultural goods remained modest. In addition, the monastic sects' landed estates meant that they had little need for daily alms, which minimized, if it did not preclude entirely, that reciprocal element in nineteenth-century Burmese Buddhism whereby villagers gave monks alms in return for Buddhist schooling of village youths and an opportunity to acquire good karma. Further retarding popular literacy was the fact that the art of writing was still in its infancy, and manuscripts were prohibitively expensive. Given these impediments, cultural standardization was necessarily limited, religious transmissions were overwhelmingly oral, pre-Buddhist spirit sacrifices remained a key ritual, and even among rural monks, literacy may have been unusual. ${ }^{9}$

In Pagan itself and major provincial centers the culture of lay aristocrats and senior monks seems to have differed from that of rural commoners in three respects. Although literacy even in capital circles was far from universal, it was certainly more widespread than among the general population. Elite culture was probably more self-consciously Burmese. And it was more expressly Buddhist. (Between ca. 1300 and 1850 we will find that all three features diffused horizontally and vertically.) Pagan monks composed texts on Pali grammar and Buddhist philosophy. At first Pali, the language of scriptures, and Mon provided the chief literary languages, both of which, of course, were inaccessible to the vast majority of Burmesespeakers. But in the early 1100s Burmese writing began to develop and within a century it had become the standard vehicle for religious inscriptions and possibly various secular materials. At the same time, as noted, Burmese colonization spread Burmese dialects and customs west beyond the original zone of settlement. Along with post-1190 epigraphic references to "Burmese" (myan-ma) people. ${ }^{10}$ and the aforementioned 1235 reference to "the Burmese country," such developments suggest an elaboration and a modest extension of Burmese culture. In the ninth century, when Burmese warriors, illiterate and animist, entered the lowlands, their numbers and cultural éclat must have been modest indeed. But given this post-1100 profile and the attraction of Burmese language, writing, and religion for

\footnotetext{
9 Victor Lieberman, Strange Parallels: Southeast Asia in Global Context, c. 800-1830, vol. 1. (Cambridge, 2003), 115-18.

${ }^{10} \mathrm{SHMK}, \mathrm{I}, 50$ contains the earliest reference so far discovered.
} 
Shan elites in the northern hills who entered the orbit of the Pagan court, Burmese norms must have become a significant element in imperial cohesion.

Clearly, however, Buddhism, not ethnic solidarity, provided the principal rationale for royal power and a spatial framework for court self-images. Unlike their post-Pagan successors, Pagan rulers, so far as we know, did not identify themselves as "kings of the Burmese" and did not equate royal interests with those of Burmese-speakers per se. Among hundreds of Pagan-era inscriptions we still have only that one reference to "the Burmese country." Courtiers and monks saw themselves inhabiting a supra-ethnic universe, a Buddhist ecumene, embracing Sri Lanka, Myanmar, and northern Thailand, wherein clerics and Pali texts circulated freely across ethnic frontiers.

\section{ETHNIC LOYALTIES IN AN ERA OF MULTISTATE COMPETITION,}

C A. $1300-1550$

The late thirteenth century initiated a sustained political shift from Upper Myanmar to more southern areas. Although western mountains, by weakening the southwest monsoon, render Upper Myanmar something of a dry zone, that region always supported a far larger population than the south both because riverine irrigation was available and because clearing light northern vegetation was easier than taming the vast swamps and swirling floodwaters of the Irrawaddy delta. Moreover, during the so-called Medieval Climate Anomaly, ca. 950-1300, dramatically stronger monsoons improved rainfall in the north, while inundating the coast, which had no mountain shield. To a considerable degree propitious climate underlay Pagan's hegemony. However, starting in the thirteenth century and intensifying ca. 1290-1480, the Little Ice Age reversed those trends. Upper Myanmar suffered droughts far more serious than those in areas to the south, while reduced flooding actually may have benefited the coast. ${ }^{11}$ Lower Myanmar in this period profited as well from a long-term increase in maritime trade, which drew on the large-scale entry of Chinese traders into Southeast Asian waters and rising Indian Ocean demand for East and Southeast Asian products. Thus strengthened, the new Mon coastal kingdom of Ra-manya not only broke away from the north but occasionally went onto the offensive. In the early 1500s the south was further strengthened by Muslim and Portuguese mercenaries equipped with light cannon and hand-held firearms.

As if these southern challenges were insufficient, from the early $1300 \mathrm{~s}$ Tai-speaking Shans launched devastating raids into Upper Myanmar from the great belt of highlands north and northeast of the basin. Various Shan

\footnotetext{
11 Victor Lieberman and Brendan Buckley, "The Impact of Climate on Southeast Asia, c. 950 1820: New Findings," Modern Asian Studies 46 (2012): 1049-96. The dry zone runs from 23 to 18 degrees north latitude before yielding to an intermediate zone of moderate rainfall, which in turn lies north of the wet coastal zone.
} 
principalities enjoyed the same two advantages as their coastal counterpartsprivileged access to firearms and to burgeoning long-distance trade-but in their case it was Chinese military contacts and the exchange of Shan-area gems for Chinese silver that proved critical. ${ }^{12}$

Beset on both south and north, Ava, which by 1365 had replaced Pagan as the northern capital, struggled vainly to restore a degree of imperial authority. Seeing the north's growing debility and strengthened by climate change and an influx of northern refugees, Ava's erstwhile dependencies along the southern fringe of the dry zone, most notably Toungoo and Prome, now laid claims to independent sovereignty, enlisting omens and prophecies of their coming grandeur. In short, the western mainland fragmented. The rump state of Ava, Ra-manya, various Shan kingdoms, newly independent Prome and Toungoo, and a number of lesser lowland principalities all began to fight and ally with one another in a desperately chaotic search for local advantage. ${ }^{13}$

How did these conditions affect political ethnicity? The results were mixed. Three factors militated against a simple fusion of ethnicity and loyalty. First, the Shan, Mon, and Burmese worlds, in each case, were far too politically and culturally fragmented to support a stable, overarching ethnic loyalty. Upland geography condemned the Shans to permanent Balkanization. Ra-manya's far-flung ports (Bassein, Pegu, Martaban) were as likely to compete as they were to cooperate, which opened the door to alliance, for example, between Burmese-led Ava and Mon-led Bassein against Mon-led Pegu. So too, Ava and its Burmese-led rivals sometimes allied with Shans or Mons against fellow Burmese. Second and by extension, Darwinian competition between post-Pagan statelets, along with the scarcity of population, led local rulers to welcome adherents regardless of origin. Most armies and courts were to some degree polyethnic, as sanctioned by a pan-ethnic aristocratic culture as well as by Buddhism, and as structured through individual patron-client ties. Bilingualism seems to have been common, and defections to serve rulers of different ethnicity bore no particular stigma. Third, frequent disorder and wartime damage joined yet modest rural productivity to limit commercial and cultural circulation that

\footnotetext{
12 Sun Laichen, "Shan Gems, Chinese Silver, and the Rise of Shan Principalities in Northern Burma, c. 1450-1527," in Geoff Wade and Sun Laichen, eds., Southeast Asia in the Fifteenth Century: The China Factor (Singapore, 2010), 169-96; idem, "Military Technology Transfers from Ming China and the Emergence of Northern Mainland Southeast Asia," Journal of Southeast Asian Studies 34 (2003): 495-517.

${ }^{13}$ On regional fragmentation ca. 1300 to 1550, see List of Microfilms Deposited in the Centre for East Asian Cultural Studies, Part 8, Burma, Tokyo, 1976, film 91, no. 11, National Library MS, 62/ 2339; "Dhamma-zei-di-min at-htok-pat-ti sa-dan," MS Birman P4, Southeast Asia Collection, Library, Ecole francaise d'Extreme Orient; SHMK, vols. III-V, passim; U Kala, Maha-ya-zawingyi, vol. I, Hsaya Pwa, ed. (Rangoon, 1926), 325-457, and II, Hsaya Pwa, ed. (Rangoon, 1932), 1-271; "Ya-za-di-yaza ayei-daw-bon," in Hsaya U Bi et al., eds., Ayei-daw-bon nga-zaung-dwe (Rangoon, 1923), 157-381.
} 
could nourish supra-local identities, whether ethnic or Buddhist. By later standards monetization remained limited. ${ }^{14}$ There was still no evidence of extensive monastic education for village youths or widespread literacy. Texts remained remarkably expensive. Feasts attended by monks, at which spirits were propitiated, cattle slaughtered, and alcohol consumed, point to the survival of pre-Buddhist traditions. ${ }^{15}$ In the Shan hills Buddhism had a yet more nominal presence.

However, in these same centuries, ca. 1300-1550, we also find trends favorable to ethnic integration and to the reorganization of the western mainland under specifically Burmese auspices. Over the long term the latter trends would prevail.

Ironically, despite its centrifugal political implications, on balance fragmentation promoted ethnic consolidation. Pagan faced no regional rival, so there was no military spur to ethnic expression. But insofar as Ava was primarily associated with the Burmese and its southern rival Ra-manya with the Mons, decades of bitter north-south warfare lent ethnicity a novel prominence. Shan raids from the fourteenth through the early sixteenth centuries had a similar polarizing effect. It is true, as I just noted, that Ava's decline invited cross-ethnic alliances. Yet insofar as Prome and Toungoo, like Ava, were still seen as primarily Burmese polities, the post-Pagan linkage between ethnicity and loyalty persisted. Recall, we have only one extant Pagan-era reference to "the Burmese country." But in inscriptions describing interregional warfare from the fourteenth through the sixteenth centuries this term was ubiquitous, regularly counterposing "the Burmese country" to "the Mon country" (talaing pyei) and "the Shan country" (shan pyei). Chronicles and inscriptions suggest that Burmese, Mon, and Shan leaders in this period commonly referred to, and sometimes pilloried, their foes in ethnic terms. ${ }^{16}$ In other words, notwithstanding diverse crosscutting trends, kingdoms assumed an ethnic character either unknown, or more pronounced than, in the Pagan period.

In large measure communal tensions grew from north-south population movements. Shan incursions into the northern lowlands offered one dramatic illustration, but by far the most demographically significant long-term shift

\footnotetext{
14 Victor Lieberman, "Secular Trends in Burmese Economic History, c. 1350-1830, and Their Implications for State Formation," Modern Asian Studies 25 (1991): 18-21.

15 SHMK, IV, 9, 13, 84, 88, 121, 206, 244-63; and V, 6-16, 67, 111; U Kala, Maha-ya-zawingyi, II, 57-58.

16 For example, $S H M K$, IV, 44, 203, 207-8, 230, 255; and V, 21, 23, 115; inscriptions \# 619, 644, 654, 670, 698, 789, 886, 916, 934, 943, 1005, 1014, and 1043, in Chas. Duroiselle, compiler and ed., A List of Inscriptions Found in Burma, Part I (Rangoon, 1921); "Ya-za-diyaza ayei-daw-bon," 164, 220, 239-40, 268-70, 337-42, 360, 369-70, 379; "Han-tha-wadi hsin-byu-shin ayei-daw-bon," in Hsaya U Bi, Ayei-dw-bon, 8, 384-85, 413, 437; and the later, but suggestive, U Kala, Maha-ya-zawin-gyi, I, 387, 427-28; and II, 22, 38, 136, 141-44, 251.
} 
was the migration between ca. 1350 and 1550 of Burmese settlers into coastal cities, and more especially rural districts between the 19th and 18th parallels that had once been predominantly Mon. Gradually, bilingual cultivators who had identified as Mons found it advantageous to adopt Burmese traits. This transition appears in the retreat of Mon place names and the steady infiltration of Burmese orthography and loan words in Mon inscriptions. ${ }^{17}$ In part, the invention by Mon monks and literati of a glorious pre-Pagan past for the southern kingdom of Ra-manya may have been a defensive attempt by some southerners to halt the erosion of Mon ethnicity. Burmese migration responded to climatic shifts and Shan pressures, but it also benefited from Burmese water control techniques superior to Mon practices, from new highyield rice strains (kauk-gyi), and from competition among southern successor states to build their agrarian base by welcoming migrants. Note, however, that as Burmese moved south, the population in Upper Myanmar remained substantially Burmese, because, along with improved rainfall after ca. 1480, some of the same agrarian innovations as we find farther south allowed northern Burmese to absorb and compensate for Shan disruptions. In effect, the basin as a whole by 1550 had assumed a more Burmese character. Our earliest censuses suggest that the Burmese population of the interior in the late 1500 s was eight or nine times larger than the predominantly Mon population of the coast. ${ }^{18}$

Rising international trade joined agrarian innovation to strengthen market linkages extending from Yunnan to the south coast. In return for gems and cotton, southwest China supplied the Shan uplands with silver. Shans in turn sent Chinese silver, local tea, and gems into the valley in exchange for salt and Indian textiles. The lowlands then funneled Chinese and Shan goods, along with local produce, to the coast, which imported Indian textiles. ${ }^{19}$ Each sector profited from this multi-stage assemblage, but as we shall see, the Burmese-led polity of Toungoo, on the southern fringe of the dry zone, became the chief beneficiary because it was able to dominate both coastal ports and Shan market centers.

The cultural counterpart to interregional trade was a modestly wider circulation of ethnic and religious norms. Not only did settlers spread Burmese speech and customs to the frontier, as just noted, but within the interior itself predominantly Burmese pilgrims, market-bound peasants, traders, monks, and entertainers diffused urban norms to provincial centers, and thence to nearby villages. Although antique orthography and hugely expensive manuscripts suggest that literacy remained an elite prerogative,

17 Lieberman, Strange Parallels, I, 133 n125.

18 Victor B. Lieberman, Burmese Administrative Cycles: Anarchy and Conquest, c. 1580-1760 (Princeton, 1984), 21-22.

19 Lieberman, "Secular Trends," 12-21. 
more diverse and numerous Burmese-language works point to a modestly wider community of readers and authors. The fourteenth to early sixteenth centuries saw, for example, new vernacular poetic genres, the first extant didactic text for students, and the first brief history of Myanmar. ${ }^{20}$ If ethnic artifacts circulated more widely, the same was true of religious texts and practices. Often at the invitation of rival rulers eager to enhance their reputation for piety, Sinhalese-oriented monks spread rituals and learning from coastal ports to inland centers and thence into the Shan hills. Within the lowlands, teetotal vows by rural landholders also testified to more orthodox Buddhist sensibilities. The thrust, imperfectly realized, of religious reform was to marginalize local customs and to enhance textual, that is to say canonical, observance. ${ }^{21}$ Everywhere Buddhism tended to enhance royal authority by preaching respect for court-sanctioned hierarchy and by celebrating the throne as guardian of monastic purity.

Did people sense a contradiction between particularist ethnic and universal religious loyalties? As befit their official image, rulers sought veneration in exclusively religious terms, as World Rulers, Kings of Righteousness, Future Buddhas, storehouses of good karma, and so forth. There was no secular theory of political legitimacy, and as a practical matter, polyethnicity demanded ecumenicism. And yet, anticipating a linkage between ethnicity and religion that would strengthen after 1550, northern courtiers and literati were quick to boast, especially in times of increased tension with Shan- or Mon-led kingdoms, that the "Burmese country" was where the Buddha's teachings were established earliest and most firmly. As foretold by Gotama Buddha, the "Burmese country" thus took precedence over Ra-manya, Sri Lanka, and all other realms. ${ }^{22}$ Our sources say little about popular opinion, but it is likely that in conflict situations some Burmese-speaking peasants touted simplified version of these official claims.

In sum, between ca. 1300 and 1550 the western mainland saw trends that adumbrated a more durable re-integration under Burmese hegemony. Burmese ethnicity expanded and grew modestly more coherent. Religious practices throughout the region became more Theravadin and more supportive of royal authority. As lowland-upland market ties thickened, Shans, their ruling elites in particular, entered more closely into the economic and cultural life

20 D. Christian Lammerts, Buddhist Law in Burma: A History of Dhammasattha Texts and Jurisprudence, 1250-1850 (Honolulu, 2018), ch. 2; Pe Maung Tin, Myan-ma-sapei thamaing (Rangoon, 1955), 35-90; Shin Thilawuntha, Ya-zawin kyaw (Rangoon, n.d.); Lieberman, Strange Parallels, I, 134.

21 Inscriptions \#780, 682, 812, 858, 977, and 982, in Duroiselle, List of Inscriptions; SHMK, IV, 72, 93-94; and V, 65. Burmese identified their practices not as "Theravada Buddhism" but merely as the "Religion" (tha-thana).

${ }^{22}$ Inscriptions \#698 and 1043 in Duroiselle, List of Inscriptions; Shin Thilawuntha, Ya-zawin kyaw, esp. $75 \mathrm{ff}$. 
of the valley. And in the western mainland as a whole the political center of gravity gravitated south, from the interior to the coast, and within the interior toward the frontier state of Toungoo.

BURMESE ASCENDANCY UNDER THE TOUNGOO KINGS, CA. 1550-1752

In the mid-sixteenth century these trends culminated in the unification of the western mainland under a Burmese dynasty from Toungoo. Strengthened by an influx of northern refugees, systematic reclamation, and his own Indian Ocean mercenaries, in 1539 the Toungoo ruler Tabin-shwei-hti (r. 15311550) overwhelmed Ra-manya, with its commercial wealth, a goal that had eluded Ava for decades. He promptly moved his capital to Pegu, on the coast, where it would remain until the century's end. With the manpower of both the dry zone and the coast at his back, Tabin-shwei-hti's more celebrated successor Bayin-naung (r. 1551-1581) went on to conquer Ava, the Shan hills, Chiengmai, and the Siamese kingdom of Ayudhya. This was arguably the largest empire in Southeast Asian history. In awe, Mons referred to Bayin-naung as "Victor of the Ten Directions."23

Ethnicity at the First Toungoo court was genuinely mixed. Although accompanied by large numbers of fellow Burmese, Tabin-shwei-hti showed his affinity for the culture of his new home by taking a Mon princess as his chief queen and by cutting off his Burmese hair-knot in favor the close-cut hairstyle of the Mons, thus "becoming a Mon" in the eyes of contemporaries. $^{24}$ His territorial vision, excluding much of the "Burmese country" in favor of an east-west coastal empire, showed no ethnic inspiration. Although he conquered Upper Myanmar, Bayin-naung also kept the capital at Pegu. His leading courtiers were diverse. "All [of us], his chosen men, in fact, whether Shans, Mons, or Burmese ... declared ourselves willing to lay down our lives [for him]," a Mon memoir declared. ${ }^{25}$

Such public expressions of comity aside, both European and indigenous accounts point to persistent tensions between Burmese and Mons, whose languages were mutually unintelligible and who were readily identifiable not only by hairstyle but by body tattoos and religious and village traditions. Some Mons clearly resented the large-scale entry of Burmese officials, soldiers, and traders, many of whom seem to have enjoyed royal favor. ${ }^{26}$ Indicative of such tensions, a self-flattering Burmese prophecy proclaimed,

23 On the First Toungoo (1486-1599), Restored Toungoo (1597-1752), and early Kon-baung (1752-1885) dynasties, see Lieberman, Burmese Administrative Cycles; idem, "Ethnic Politics in Eighteenth-Century Burma," Modern Asian Studies 12 (1978): 455-82; idem, Strange Parallels, I, ch. 2.

24 U Kala, Maha-ya-zawin-gyi, II, 214-15.

25 Phra Candakanto, ed., Nidana Ramadhipati-katha, H. L. Shorto, trans. (Pak Lat, Siam, 1912), 152.

${ }^{26}$ Lieberman, Strange Parallels, I, ch. 2, notes 111, 112, and 189. 
"Talaings [Mons] will carry burdens and Shans will plough the field. Indeed they will be servants of the Burmese."27

Had the dynasty remained at Pegu for several generations, conceivably the Burmese-Mon synthesis of which Tabin-shwei-hti dreamed would have been realized. In the event, however, the empire disintegrated in the $1590 \mathrm{~s}$ through military overextension in Siam and uncontrolled autonomy in the Irrawaddy lowlands. As the collapsing dynasty sought to save itself by imposing ever-heavier services and taxes on the southern population, widespread revolts, led by Mon monks, expressed southern fear and hatred of the Toungoo monarchy.

A branch of the fallen house, based in Upper Myanmar, restored the empire in the early seventeenth century, but introduced a number of structural changes designed to remedy the manifest weaknesses of the previous regime. The Restored Toungoo Dynasty (1597-1752), as it is known, abandoned claims to Siam in favor of a more compact realm along the Irrawaddy axis. They reduced the danger of provincial rebellion by replacing princely heads with governors of more humble rank and by systematically enhancing the capital's military superiority. And they shifted the capital itself from Pegu to the "Burmese country," where at Ava or nearby sites it would remain until the British conquest. ${ }^{28}$

It would be wrong to see the return upriver primarily as an expression of Burmese chauvinism. There was a perfectly cogent geopolitical rationale: located in what was traditionally the most productive agrarian zone, Ava remained a logical site for the capital. The new system of provincial supervision let Burmese kings reside in the populous interior while keeping control over the guns and trade of the coast. In effect, Restored Toungoo kings now learned to walk on two legs. Like all previous dynasts, they presented themselves in universal religious terms. The most celebrated dynastic figure, Tha-lun (r. 1629-1648), took care to inscribe dedications for his chief religious donation in the three chief languages of the empire, Burmese, Mon, and Yun (Tai).

Nonetheless, as a practical matter the move to Ava reduced royal patronage of non-Burmese clients. To the 1660s some Mons still served as senior officials, but thereafter Mons obtained progressively fewer and more humble posts at court, in the monastic hierarchy, and most disturbing to them, in the administration of Lower Myanmar itself. ${ }^{29}$ It was natural

27 "Han-tha-wadi hsin-byu-shin," 408, which, although written later, agrees with Nidana, 158.

${ }^{28}$ Victor Lieberman, "The Transfer of the Burmese Capital from Pegu to Ava," Journal of the Royal Asiatic Society 112, 1 (1980): 64-83.

${ }^{29}$ Lieberman, Burmese Administrative Cycles, 214; Alexey Kirichenko, "From Thathanadaw to Theravāda Buddhism: Constructions of Religion and Religious Identity in Nineteenth- and Early Twentieth-Century Myanmar," in Thomas David DuBois, ed., Casting Faiths: Imperialism and the Transformation of Religion in East and Southeast Asia (New York, 2009), 28-29. 
perhaps that families nearest the capital would have had the ear of the court. But whatever the explanation, decreasing patronage alienated southern leaders and reinforced the message of continuous northern immigration and heavy taxes that Ava no longer functioned in the interests of southern society. In the late 1500s Mons in the delta were said to have been "as numerous as the hairs on a bullock, whereas we Burmese are as few as the horns." 30 But by 1740 Mons had been reduced to some 60 percent. $^{31}$ As early as 1677 Dutch traders reported that Mons "at present are tormented above all others" and "are just looking for a suitable opportunity to rid themselves of Burmese domination and to take revenge ... for their tyrannical behavior.",32

From 1740 to 1757 these tensions exploded in a major revolt at Pegu, a regional expression of political ethnicity, which, to recall my definition, invoked ethnic symbols to identify leaders and followers as members of a state-centered collectivity seeking resources in competition with other groups. Although not a few local Burmese who had been excluded from Avan patronage joined the uprising and although it was led initially by a man who claimed to be a fugitive Burmese prince, contemporary Mon chronicles claimed that the rising would restore the greatness of Ra-manya as a quintessentially Mon kingdom. The rebels massacred large numbers of Burmese at Pegu and subsequently demanded that Burmese serving the new southern court cut their hair in Mon fashion, in effect that they (like Tabinshwei-hti two hundred years earlier) change ethnicity.

In the event, however, Pegu's 1752 conquest of Upper Myanmar sparked a vengeful, ultimately victorious countermovement under the northern Burmese leader Alaung-hpaya, founder of the Kon-baung Dynasty (1752-1885), who deliberately appealed to Burmese solidarity. While welcoming individual Mon clients, the new strongman did not hesitate to invoke anti-Mon stereotypes and to kill Mon prisoners, while sparing Burmese. Although some clienteles in both north and south remained polyethnic, "Burmese" quickly became a shorthand for pro-northern, and "Mon" for pro-southern, allegiance. $^{33}$

Again one may ask: how was Burmese loyalty reconciled with Buddhist universalism? Prophecies and omens proved that Mons could never rule Lower Myanmar, Burmese claimed, because Burmese were the "foremost (u-zun) people." Their king, whose good karma was unequaled and whose coming had been prophesied, was fated to subdue not only Mons, but Shans,

\footnotetext{
30 "Han-tha-wadi hsin-byu-shin," 389.

31 H. L. Shorto, personal communication, 1974. The other 40 percent were a mix of Burmese, Karens, and Siamese.

32 Algemeen Rijsarchief, The Hague," Overgekomen brieven en papieren," Codex 1323, 1835-

33 Lieberman, Burmese Administrative Cycles, ch. 4; idem, "Ethnic Politics"; and the next note.
} 37. 
Siamese, Chinese, Manipuris, and Indians. ${ }^{34}$ In extending his conquests Alaung-hpaya - whose title means "Embryo Buddha" — had but one goal: to extend benevolence to all people by spreading True Doctrine. Thus, on invading Siam, he announced that the Lord Buddha's religion did not shine brightly in that country and, regretfully despite the loss of life, he was obliged to revive it. $^{35}$ Who could deny the following syllogism?: The Religion (tha-thana-daw) offered mankind's only route to salvation. Burmese kings championed the Religion more fervently than any other rulers. Therefore, Burmese dominion was proleptically universal.

\section{A MATURE SYNTHESIS TO 1830}

From 1752 to 1830 , under early Kon-baung rule, three long-standing trends became unprecedentedly salient. Burmese culture in the lowlands grew more uniform vertically and horizontally. Burmese culture was increasingly influenced by canonical Buddhism. And Burmese culture came to dominate all of western Mainland Southeast Asia. ${ }^{36}$

Self-made and battle-tested, Kon-baung leaders were more successful than their immediate Toungoo predecessors in concentrating manpower, supervising the provinces, and projecting military power beyond the basin. Directly and indirectly, they used their authority to define and promote central usages, sponsoring orthographic, legal, literary, and monastic reforms in the knowledge that provincial elites, seeking emulatory prestige and royal favor, would follow their lead. They repressed fresh southern revolts, sponsored Burmese colonization, and sought to spread Burmese Buddhism into the hills. Above all, sustained Kon-baung warfare-against Mon rebels, Siam, Manipur, and Chinese invaders - stoked Burmese pride and popular identification with the throne. The impact of military triumphs on the popular imagination appeared in prophecies, poetry, chronicles, and foreign accounts alike. ${ }^{37}$

But clearly there was also an economic root to the growing vitality of Burmese culture. Rising foreign demand from ca. 1680 to 1830 stimulated

\footnotetext{
34 For expressions of Burmese superiority over other ethnicities, see Hkin Hkin Sein, ed., Alaung-min-taya amein-daw-mya (Rangoon, 1964), 9, 12-17, 28-30, 95-96; British Library, London, MS Orient 3464, 142-43; Kon-baung-zet maha-ya-zawin-daw-gyi, U Tin (Mandalay), compiler, vol. 1 (Rangoon, 1967), 104-5, 122, 237; Let-we-naw-yahta, "Alaung-min-taya-gyi ayei-daw-bon," in U Hla Tin, ed., Alaung-hpaya ayei-daw-bon hnasaung-dwe (Rangoon, 1961), 29; Than Tun, ed., The Royal Orders of Burma, A.D. 1598-1885, 10 vols. (Kyoto, 1983-1990), III, 98-101, 144-46; Lieberman, Strange Parallels, I, 193-200.

35 Alaung-min-taya amein-daw-mya, 12-15, 28-33, 85, 175-84, 212-13; Kon-baung-zet, 233, 311, 313; British Library MS 3464, 146-47. See similar claims under Bo-daw-hpaya in Than Tun, Royal Orders, IV, 75, 83, 388, and V, 433.

36 For documentation of this section, see note 23 supra.

37 See notes 34 and 35, supra; and Soe Thuzar Myint, The Portrayal of the Battle of Ayutthaya in Myanmar Literature (Bangkok, 2011).
} 
the cotton, teak, and shipbuilding sectors, while imported textiles, along with New World silver, drew peasants to the market and lubricated urban-village exchange. Myanmar's rural economy benefited as well from Kon-baung pacification, from moderately improved weather, and from a further expansion of kauk-gyi rice and cotton cultivation. Symptom and cause of rising output, between 1635 and 1802 both the overall population and the number of local markets rose 30 to 50 percent. The population of key provincial market towns increased by 50 to 100 percent. Written contracts (thet-kayits) multiplied rapidly. By 1780 land sales, once conducted in a mix of cash and in-kind goods, were almost exclusively in cash, and taxes were substantially monetized. ${ }^{38}$

How exactly did economic shifts promote cultural integration? First, more rapidly than in earlier centuries, commercial ties between centers within the Irrawaddy basin and between the basin and the Shan hills sped the circulation of colonists, pilgrims, monks, seasonal laborers, peddlers, puppeteers, singers, musicians, dancers, and actors. Primarily Burmesespeakers, these cultural agents exposed isolated communities to supra-local forms of speech, more orthodox forms of Buddhism, and court-oriented notions of social hierarchy.

Second, greater rural wealth and a growing demand for commercial and administrative literacy accelerated a late Toungoo expansion in village monasteries and schools. Whereas in the fifteenth century literacy still seems to have been an elite monopoly, perhaps by 1700 and certainly by 1830 , some 50 percent of Burmese males were functionally literate. Before the late seventeenth century regional centers could not compete with scholarly monasteries in the capital, but thereafter monasteries patronized by wealthy provincial laymen began to rival capital establishments. ${ }^{39}$ As literacy rose and as readers, lay authors, and oral recitations proliferated, Burmese literature grew more socially inclusive in genre, theme, style, and setting.

Third, economic growth strengthened the state, hence its ability to advance Burmese and Buddhist norms directly and indirectly. Literacy aided the collection and dissemination of information. Religious education in the villages promoted reverence for the ruler as moral exemplar. Most fundamentally, increases in population, foreign trade, and imported guns joined administrative reform to boost the throne's military capacity and ambition. Similar changes were strengthening Siam and China, Burma's

\footnotetext{
38 Lieberman, "Secular Trends," 23-25.

39 In the late $1700 \mathrm{~s}$, however, the success of provincial monasticism joined sangha reforms to open royal monasteries at the capital to infiltration from the villages. This produced still more effective capital-provincial integration, but in the long run reduced the prestige of provincial establishments. Alexey Kirichenko, "Dynamics of Monastic Mobility and Networking in 17thand 18th-Century Upper Burma," in D. Christian Lammerts, ed., Buddhist Dynamics in Premodern and Early Modern Southeast Asia (Singapore, 2015), 333-72.
} 
chief rivals. Warfare of course had long been endemic across the region, but arguably it was the growing scale and demands of interstate competition in the eighteenth and early nineteenth centuries that provided the principal spur to ethnic mobilization. ${ }^{40}$

Consider how these processes combined to modify culture in Upper Myanmar, Lower Myanmar, and the Shan hills, respectively. In Upper Myanmar, the formation of ethnically disparate military service (ahmu-dan) units underscored the court's distinctly pre-nationalist ethos. Yet the larger trend towards Burmese ethnic integration was clear. Regional courts and regional rebellions became a thing of the past. Imperial histories supplemented and supplanted regional histories. Dialect differences receded. Formerly polyethnic districts in the far north became heavily Burmese. Expressions of Burmese chauvinism became more common. The same exposure to standardized norms as promoted Burmese ethnicity also encouraged religious orthodoxy. Monks and laymen joined to disseminate texts, to strengthen monastic standards, and to repress alcohol and opium use, animal slaughter, prostitution, and spirit (nat) propitiation. Kon-baung kings abandoned pre-Buddhist origin myths to claim descent from Gotama Buddha, while northern scholars strove to align law codes more closely with Buddhist scriptures. $^{41}$ In 1550 the imperial court had been genuinely polyethnic, but by 1770 Burmese completely dominated the court, and to local people and foreign visitors alike the empire had become identified, indeed synonymous, with its northern core ethnicity.

In southern Myanmar, following Alaung-hpaya's re-conquest, separatist and assimilationist responses continued, but both responses led ultimately only in one direction: more complete Burmanization. Officials readily accepted Mon culture so long as it remained apolitical. The court never considered demanding systematic Burmanization because, as I indicated, there was no vocabulary, no theoretical imperative to elevate ethnicity over patron client ties and Buddhist universalism. Absent local challenges to Burmese preeminence, the court was content to leave Mons in peace. But six fresh southern revolts to 1826 prompted severe repression followed by largescale Mon flight to Siam. At the same time fresh waves of Burmese entered the cities, shipyards, and countryside of the south. Whereas Burmese in 1500 had been a tiny minority in the Mon delta, by 1830 Mons had been effectively reduced to delta pockets and districts beyond the Sittang River.

Across the great Tai-speaking uplands, which may have contained a third as many people as the central basin, Burmese influence, Buddhism in particular, also advanced, albeit at more elite levels and without Burmese

\footnotetext{
${ }^{40}$ A secondary, economically linked spur to ethic "otherness" may have been increasing contact with foreign traders.

${ }^{41}$ Lammerts, Buddhist Law, ch. 5.
} 
ethnicity making inroads. As in the Toungoo era, the key mechanisms were movements of Burmese and Shan monks and traders, marriages between Burmese and Shan aristocrats, Burmese royal patronage, and Shan participation in imperial ceremonies and military campaigns. Through such channels Tai-Shan scripts, calendars, measurements, architecture, and Buddhist practices increasingly followed Burmese models. ${ }^{42}$ Thus a cultural system focused on the Burmese lowlands cohered all across the western mainland.

\section{MYANMAR AND BRITAIN: A PRELIMINARY SCHEMA}

Expanding my introductory comments, I conclude with a synoptic comparison of political culture in Western Europe as exemplified by Britain, and in Myanmar, which I suggested (but lack space to show in detail) was broadly representative of several Asian rimlands. While arguing that political ethnicity in those two regions shared hitherto unrecognized features, I also identify elements unique to Europe that propelled political ethnicity toward modern nationalism. ${ }^{43}$

Britain and Myanmar may seem like an odd pairing, given that by 1820 Britain was en route to becoming the first industrial nation, whereas Myanmar was agrarian, relatively poor, and about to become a British colony. In fact, however, they exhibited uncanny developmental parallels. In both realms, which in 1400 were of like size and population, an economically privileged core, the Irrawaddy basin or southeast England, expanded its authority over more thinly populated peripheries. In marginalizing rival cultures, both core ethnicities claimed a privileged relation to religious truth. Chronologies of integration were quite similar. So too were underlying dynamics: disproportionate economic growth in the core, commercially driven cultural circulation, multiform state patronage, and intensifying warfare. In both Myanmar and Britain ethnicity joined rulers and subjects in a fashion inconceivable in those vast Eurasian realms (Qing China, Mughal India, the Ottoman domain) ruled by Inner Asian conquest elites.

Consider briefly then the progress of ethnic politicization in Britain. During the same period ca. 900-1300 as Burmese-led Pagan established a novel dominion over parts of the western mainland, southeastern England developed a cultural template that would transform the British archipelago. On the eve of the Norman conquest, Anglo-Saxon literati portrayed the rex

42 Shan Thammasat Manuscripts, Sai Kham Mong, compiler (Tokyo, 2012); Sao Saimong Mangrai, The Padaeng Chronicle and the Jengtung State Chronicle Translated (Ann Arbor, 1981). Cf. Daniel Veidlinger, Spreading the Dhamma (Honolulu, 2006).

43 For basic sources on English history see, inter alia, Short Oxford History of the British Isles, Paul Langford, general editor, vols. 2-9 (Oxford, 2000-2010); and my Embracing the World, ch. 8. 
Anglorum as ruler of a distinctive people and elevated Old English, alongside Latin, as a kingdom-specific literary and legal vehicle. If the Norman conquerors and their Plantagenet offshoots decimated the Anglo-Saxon aristocracy and tied Britain more closely to the continent in a sprawling cross-Channel empire, they also synthesized Norman and Anglo-Saxon elements to modify, and ultimately strengthen, English identity. By 1400 Middle English dialects were spoken by all classes and a recognizably English literature had cohered. Fourteenth-century literary sources presented the kingdom of England as a discrete moral and spiritual entity whose people were collectively responsible to ensure the welfare of the realm by remaining in God's favor. ${ }^{44}$ Not long after Pagan-era colonists moved west of the Irrawaddy, Anglo-Norman, that is to say English, colonists expanded in Wales and Ireland, marginalizing local languages and social customsoften condemned by the newcomers as "filthy abominations" and "enormous vices."45 Scotland remained independent, but the Scottish lowlands selfAnglicized. In brief, although cultural integration by 1300 was more pronounced in Britain than in Myanmar, in both realms the core imperial culture enjoyed a novel extension.

As in Myanmar, so too in Britain the late fourteenth and fifteenth centuries partially reversed earlier trends. Plague, economic contraction, foreign defeats, and civil war reduced English influence in Ireland and forced England onto the defensive against Scotland. Yet, again as in Myanmar, with accelerating force from the sixteenth through the eighteenth centuries, imperial fortunes revived, and core ethnicity grew ever more hegemonic. Landholding, and to a lesser extent mercantile, elites throughout England became more receptive to southeastern styles of consumption, architecture, and dress. Local resistance to Anglicization notwithstanding, similar motifs gradually modified rural and urban life in much of Wales, Ireland, and Scotland. Partly to forestall foreign interventions, an ever-more-powerful London-centered state brought all three of these regions into its political orbit between 1535 and 1801. Thus from 1535 to 1542 England effectively annexed Wales and declared Ireland a kingdom joined to England through the person of the ruler. In 1707 Scotland and England merged to form the Kingdom of Great Britain, and in 1801 Great Britain and Ireland joined to form the United Kingdom with a single Parliament. Reinforcing constitutional integration, in Ireland sustained Anglo-Scottish assaults on Gaelic culture were more ruthless, if ultimately less successful, than contemporary Burmese attacks on Mon civilization. As Shan and Mon leaders sought to reconcile local identities with an overarching Burmese imperial loyalty, so Welsh, Scottish, and Anglo-Irish,

\footnotetext{
44 Andrea Ruddick, English Identity and Political Culture in the Fourteenth Century (Cambridge, 2013), 305, and chs. 2-6, passim.

45 Krishan Kumar, The Making of English National Identity (Cambridge, 2003), 83.
} 
as well as English, elites struggled to harmonize long-standing regional affiliations with an emergent British identity. ${ }^{46}$

How, then, shall we explain these halting, but sustained movements in Britain and their strange coordination with Myanmar? As befit overwhelmingly agrarian economies, the shift from prosperity ca. 900-1300 to depression ca. 1300-1450/1500 reflected, above all, a hemisphere-wide change from the agriculturally beneficent Medieval Climate Anomaly (ca. 900-1300) to the Little Ice Age. At the same time as hemispheric warming to ca. 1300 strengthened the monsoons in Southeast Asia, it extended the growing season and dried out fertile, but hitherto waterlogged bottomlands in parts of northern Europe. In both regions this produced a substantial, ultimately unsustainable expansion of population and cultivation that went into reverse with the turn to colder conditions during the fourteenth and much of the fifteenth centuries. ${ }^{47}$ Thereafter climate continued to influence output, but from ca. 1500 to 1800 the diminished amplitude of climate fluctuations and the rising volume and complexity of global trade meant that coordination between Britain and Myanmar reflected chiefly the synchronizing impact of Japanese and American bullion flows, New World crops, Indian textiles, and European-style firearms. Even if population and wealth in core and periphery grew at the same pace, the former's initial superiority ensured a self-reproducing absolute advantage. In fact, however, growth rates in southeast England and the Irrawaddy basinboth of which combined privileged access to maritime trade with agricultural superiority — normally exceeded those in outer areas.

Intertwined with quantitative expansion were structural transformations in both economies, as monetization became universal and regional autarky receded. More rapidly than in Myanmar, by the mid-1600s Britain was evolving from a network of regional economies to a national economy. ${ }^{48}$ The dramatic expansion of Britain's overseas empire in the eighteenth and early nineteenth centuries, with its attendant career opportunities, only deepened the inclination of ambitious Scots, Welsh, Anglo-Irish, and north Englishmen to join their fortunes to those of Englishmen in the southeast.

As in Myanmar, culture tended to follow economic change. In truth, across much of England culture/ethnicity was being standardized and

\footnotetext{
46 On the progress of British integration, see Paul Langford, Englishness Identified: Manners and Character,1650-1850 (Oxford, 2000); Linda Colley, Britons: Forging the Nation, 17071837, rev. ed. (New Haven, 2009); Colin Kidd, British Identities before Nationalism: Ethnicity and Nationhood in the Atlantic World, 1600-1800 (Cambridge, 1999); Alexander Grant and Keith J. Stringer, eds., Uniting the Kingdom? The Making of British History (London, 1995); Brendan Bradshaw and Peter Roberts, eds., British Consciousness and Identity: The Making of Britain, 1533-1707 (Cambridge, 1998).

47 Victor Lieberman, "Charter State Collapse in Southeast Asia, c. 1250-1400, as a Problem in Regional and World History," American Historical Review 116, 4 (2011): 937-63.

48 Steve Pincus, 1688: The First Modern Revolution (New Haven, 2009), ch. 3; Robert C. Allen, The British Industrial Revolution in Global Perspective (Cambridge, 2009).
} 
politicized through market networks, saints' cults, sermons, popular festivals, pilgrimage, and clerical circuits three hundred years before the first printing press in 1476. But thereafter printing joined the Reformation emphasis on Bible reading and the enhanced practical value of literacy and numeracy in a commercializing society to support a sustained expansion in schools, literacy, and reading materials. Recall that in Myanmar we saw a similar link between commerce, religious reform, and vernacular education. Familiar too in its homogenizing thrust was the movement of producers to the market, colonists to the frontier, and students and laborers to urban centers. As Britain's chief port, government and financial center, home to the printing industry, and hub of a growing road network, London by the late seventeenth century had become a cultural arbiter whose styles radiated across the archipelago. The result was continuous pressure to unify culture (at least on an elite level) throughout England, to standardize English ethnicity, and to Anglicize language and culture among the gentry and educated townsmen in Wales, lowland Scotland, and parts of Ireland-in effect, to nurture an as yet inchoate, English-inflected British ethnicity.

Again as in Myanmar, the relation between economic and cultural integration, on the one hand, and state strengthening, on the other, was synergistic. Particularly from the mid-1600s Atlantic trade joined domestic economic vitality to swell the state's resource base. Monetization and literacy aided tax collections, while, as just noted, cultural standardization favored identification with the imperial center. But in reciprocal fashion British officials grew the economy through banking reforms, infrastructural investments, aggressive colonial acquisitions, and sustained, generally productive mercantilist economic interventions. The crown shaped English and ultimately British identity by repressing Catholics and Dissenters, defining linguistic and aesthetic norms, and providing status-conscious provincials an incentive for self-Anglicization. At the same time, the English/ British state, like its Burmese counterpart, politicized ethnicity, both deliberately and inadvertently, through recurrent military conflict. As early as the Hundred Years War English sermons, ballads, and popular verse explained that that Frenchmen were effeminate and that God was "usually English."49 During sixteenth-century struggles with Spain and the epic Anglo-French contests of 1689-1815 - which overlapped with large-scale Burmese-Siamese warfare - contrasts between Protestant truth and Catholic "superstition, servitude, and poverty" helped English, Welsh, and Scots forge their new British persona. ${ }^{50}$ Growing exposure to non-European peoples also nurtured a sense of "otherness," but war was the main catalyst. The same was

\footnotetext{
49 Christopher Allmand, The Hundred Years War: England and France at War c. 1300-c. 1450, rev. ed. (Cambridge, 1989), 138.

50 Colley, Britons.
} 
demonstrably true during this period in Siam, Vietnam, Sri Lanka, and Korea, not to mention other European realms, all part of Eurasia's protected zone. ${ }^{51}$

If comparable, synchronized processes encouraged integration in Britain and Myanmar, until about 1600 broadly similar theoretical understandings of the relation between cosmic power, sovereign authority, and social hierarchy also informed both realms. Exclusive sovereignty lay with the monarch, whose dynastic and personal authority derived from cosmic law. English and Burmese ethnicity were privileged, but both empires were decidedly polyethnic. And because each monarchy was dedicated to the salvation (idiosyncratically defined, of course) of all its subjects, its embrace of secular cultural was subordinate to religious themes. Social inequality, sanctioned by God/karma, was inherently moral because without hierarchy, social order was inconceivable. As subjects dependent upon royal direction, in both realms the vast majority, in theory if not in practice, lacked political agency.

Yet while in Myanmar these beliefs survived into the colonial era, England by the seventeenth century had begun to introduce critical changes. Parliament, speaking on behalf of the "whole realm" of the political community of the kingdom ${ }^{52}$ - which in fact meant propertied interests represented in Parliament-sought to reduce the distance between the monarchy and society, and to that end, evolved an ideology that was expressly English, Protestant, and eventually anti-absolutist. This thought system proved sufficiently persuasive to dethrone and execute Charles I, but inadequate to produce a stable alternative to monarchy. The Glorious Revolution of 1688 attempted to resolve this contradiction by redefining the polity as a balanced union of royal and parliamentary power. Subsequently, the balance shifted by widening the electorate and by further strengthening the authority of the legislature. The emergence in the eighteenth century of a system of parliamentary politics laid the foundation for a tradition of party government. In turn, the political stability of the eighteenth century, many argue, helped Britain absorb the upheavals of industrialization without political revolution or social breakdown. In 1830 neither England nor Britain was yet a democracy, but they were headed in that direction. In Paul Langford's formulation, the eighteenth century made government parliamentary, while the nineteenth century made it democratic. ${ }^{53}$

51 See Lieberman, Strange Parallels, I, chs. 3 and 4; Michael Roberts, Sinhala Consciousness in the Kandyan Period 1590s to 1815 (Colombo, 2003); JaHyun Kim Haboush, The Great East Asian War and the Birth of the Korean Nation (New York, 2016).

${ }_{52}$ Michael J. Braddick, State Formation in Early Modern England c. 1500-1700 (Cambridge, 2000), 23.

53 Paul Langford, A Polite and Commercial People: England 1727-1783 (Oxford, 1998), 683. See, too, Pincus, 1688; Edmund S. Morgan, Inventing the People: The Rise of Popular Sovereignty in England and America (New York, 1988); J.C.D. Clark, The Language of Liberty 1660-1832: Political Discourse and Social Dynamics in the Anglo-American World (Cambridge, 1994). 
In short, by 1830 some basic features that England had shared with Myanmar in 1600 - exclusive royal sovereignty, rigid hierarchy, popular passivity — had been modified or rejected entirely. Likewise, notwithstanding Anglicanism's tepid universalism and the ever more robust ambition of British imperialism, a concatenation of factors produced a closer fit between culture and territory: the end to English claims in France, the inclusion of Wales, Scotland, and Ireland by 1801 in the Parliament of the United Kingdom, and efforts to imbue the British Isles with a more coherent personality. Unresolved tensions between British and sub-British identities aside, England and Britain both embodied recognizable, if peculiar, versions of nationalism as defined in my opening comments.

To rephrase, then, my initial question: Why within the protected rimlands did political ethnicity evolve into nationalism in only one sector? Why in origin were nationalism and democracy exclusively West European?

In part, surely, because of distinctive cultural and legal traditions. I suspect that notions of ancestral lineage and "blood ties" provided a stronger basis for collective identities among Anglo-Saxons and Anglo-Normans than among pre-1300 Burmese. Although by the late eighteenth and early nineteenth centuries Burmese poetry and chronicles were tracing the origin of the Konbaung dynasty to the Sakyan lineage of Gotama Buddha, those claims did not speak to the ancestry of Burmese people at large, and in general notions of shared kinship were of little or no significance in defining Burmese ethnicity. ${ }^{54}$

By contrast, by the late Anglo-Saxon period the concept of gens had mutated from its restricted original meaning of family/lineage to designate a people united by shared (mythic) ancestry and rights. ${ }^{55}$ The authority of English and Scottish kings rested in part on that basis, and despite the Norman conquest, it is unlikely that those traditions lost their popular resonance. More certainly, medieval British law accorded legal protections that came to assume a national character. Originally restricted to the king's principal vassals, security against arbitrary seizure and fines gradually was extended to the generality of property holders. So too, the privileges of towns, universities, and Parliament-including Parliament's right to convene and to approve taxes-became enshrined in law and tradition. By the seventeenth century the principle was well-established that the king was merely the custodian of the common law (the accumulation of precedents based on collective reason and experience) and that, far from being the

${ }^{54}$ William J. Koenig, The Burmese Polity, 1752-1819: Politics, Administration, and Social Organization in the Early Kon-baung Period (Ann Arbor, 1990), 86-87; U Maung Maung Tin, Myan-ma sa-pei thamaing (Rangoon, 1955), 197-98; The Glass Palace Chronicle of the Kings of Burma, Pe Maung Tin and G. H. Luce, trans. (Oxford, 1923), ix-xxii, 1-6.

${ }_{55}$ Michael Braddick, personal communication, Apr. 2020. 
fountainhead of law, he was himself constrained by statute. "Freeborn Englishmen" proudly invoked their rights and immunities under the law, whose alleged violation became a principal source of grievance against the crown. So intertwined were legal entitlement and English identity that activists laid claim to that civic inheritance as often as to actual ethnicity. ${ }^{56}$

To these notions of collective entitlement and protection, Myanmar offered no close parallel. The Burmese king met with a council of ministers (hlut-daw) to discuss policy, but that body had no legal power to constrain royal actions. The first king of the world traditionally was said to have copied Burmese laws from the boundary wall of the universe. And although scholars by the eighteenth century accepted that statutes in fact had been promulgated by successive monarchs on earth, the law continued to be seen as exclusive emanation of royal power. While kings were expected to conform to Buddhist morality and avoid arbitrary oppression (pa-pathat), apart from very occasional expressions of monastic disapproval, there was no enforcement mechanism. Nor, although disputants had the option of seeking private arbitration, were rulings by royally appointed judges in the countryside subject to regular review. ${ }^{57}$

A medieval legacy no less conducive than English law to the development of national personality was Latin Christendom's distinction between the universal church and the territorial kingdom. Early medieval realms had tended to Caesaropapism, that is to say, the subordination of religious to royal authority. But by strengthening the division between the church and secular powers and by granting Rome an exclusively universal jurisdiction,

56 Patrick Collinson, "Conclusion," in P. Collinson, ed., The Sixteenth Century: 1845-1603 (Oxford, 2002), 231; Peter Lake and Steven Pincus, eds., The Politics of the Public Sphere in Early Modern England (Manchester, 2007), 34, 36; Harold J. Berman, Law and Revolution: The Formation of the Western Legal Tradition (Cambridge, Mass., 1983), pt. II; Brian M. Downing, The Military Revolution and Political Change: Origins of Democracy and Autocracy in Early Modern Europe (Princeton, 1992), ch. 2; and most especially, Michael Braddick, The Common Freedom of the People: John Lilburne \& the English Revolution (Oxford, 2018). To what extent did Greek and Roman notions of republicanism/democracy also influence early modern British thought? Certainly, the Renaissance rediscovery of classical themes-legal corporatism, political representation, citizenship rights - spread beyond the Alps and across the continent. By the sixteenth century, British humanists were extoling not religious devotion, but Roman civic commitment as the highest virtue. And if the English Revolution of 1642-1660 drew on Biblical themes, eighteenth-century writers invoked Rome, not ancient Israel, as the primary metaphor for political community. Patrick Collinson, "Introduction," 11; John Guy, "Monarchy and Counsel: Models of the State," 138-42; Greg Walker, "The Renaissance in Britain," 145-47; and Patrick Collinson, "Conclusion," 232-36, all in P. Collinson, ed., The Sixteenth Century: 1845-1603 (Oxford, 2002); Pasi Ihalainen, Protestant Nations Redefined: Changing Perceptions of National Identity in the Rhetoric of the English, Dutch, and Swedish Public Churches, 16851772 (Leiden, 2005), 22, 447-71, 591, 593; Martin van Gelderen and Quentin Skinner, eds., Republicanism: A Shared European Heritage, vol. 1 (Cambridge, 2002), chs. 2, 4, and 5. Yet, without minimizing those influences, there is reason to think that they were generally more elitist and less broadly influential than were indigenous legal traditions.

${ }^{57}$ Lammerts, Buddhist Law, chs. 6 and 7. 
the Papal Revolution of the eleventh to thirteenth centuries induced each Christian ruler to identify more closely with a named territory and people. ${ }^{58}$ In abandoning nominal claims to universal religious authority, Catholic kingdoms therefore diverged from Theravada Buddhist-as well as Orthodox Christian, Confucian, and Muslim-polities. To repeat, although the Burmese might claim superior religious virtue, they lacked the theoretical language, the conceptual apparatus, to transform Theravada Buddhism from a universal into an ethnically exclusive religion.

By formally and irrevocably fragmenting Christendom, the Protestant Reformation reinforced English and British individuality. Although in origin the Reformation in England was purely jurisdictional, an assertion of royal prerogative vis-à-vis Rome, it came to assume broad cultural and political significance. Disseminating vernacular translations of the Bible and proclaiming themselves and their followers to be the new Israel, zealous Protestants helped to nationalize sanctity and pioneered an anti-Catholic patriotism which energized English/British opposition to Spain and France and which has been termed "the most consistent English political stance of the early modern period." 59 Yet, ironically, because the upheavals of 1534 1688 showed the toxicity of sectarian enthusiasm and because the Church of England found itself forced to cohabit with dissenters and Catholic recusants, in the long term the Reformation had the unintended effect of encouraging a degree of tolerance. Recoiling against religious contention, many in England, Scotland, and Wales came to embrace the state as an instrument less of confessional uniformity than of domestic peace, and to regard empirical inquiry rather than received doctrine as an avenue to truth. At the same time, by promoting private Bible study, which had the effect of universalizing the clergy, the Reformation joined literacy and rising consumerism to encourage individual agency, which reinforced the transition from subjecthood to citizenship.

Thus, in parts of Britain a distinct legal heritage, an early fusion of political and secular culture, and Christian fragmentation joined to nourish national, proto-democratic orientations. Ultimately, however, to explain discursive and institutional divergences of such magnitude, one must also weigh physical and material factors. Take geography. In the early fourteenth century the British and Burmese realms both enjoyed an organic cohesion from the grouping of underpopulated zones, many in upland terrain, around an agriculturally and commercially privileged lowland core. However,

${ }^{58}$ Berman, Law and Revolution, pt. I; Joseph R. Strayer, Medieval Origins of the Modern State (Princeton, 1970), 20-23.

59 Diarmaid MacCulloch, "The Change of Religion," in Patrick Collinson, ed., The Sixteenth Century: 1845-1603 (Oxford, 2002), 99. Also idem, The Reformation: A History (New York, 2005), ch. 12 and passim. 
Britain's island geography, and its location on the far periphery of Europe, were considerably more conducive to imagining and integrating discrete territories than were the vast highlands that march unbroken from the northern Irrawaddy basin and the Shan Hills into the Himalayas. Already by the eleventh century, if we may extrapolate from Kathy Lavezzo's work on England, territorialized concepts of ethnicity were more developed in England than in the Irrawaddy basin. ${ }^{60}$

By extension, the difficulty of trans-montane trade west, north, and east of the Irrawaddy basin; the modest size of Myanmar's urban market; and above all, Myanmar's distance from the main east-west maritime trade routes, all ensured that by 1500 Burmese urbanization, commercial integration, and monetized exchange already were less developed than Britain's. Thereafter, as Britain came to dominate the vast Atlantic system and as British agriculture, manufacturing, and marketing underwent major structural change, disparities became ever more cumulative. Best estimates are that the Burmese economy grew some 70 percent between 1600 and 1800 , but that British national income rose 500 percent in the eighteenth century alone. ${ }^{61}$

As well as any factor, economic intensification and colonial rivalries explain the strength of English and British nationalism. What has been termed the fiscal/military state arose largely to prosecute civil wars and Anglo-Dutch wars in the seventeenth century, and then the global contest with France. From 1680 to 1815 the British state's share of national income rose from some 4 percent to 20 percent. Along with the growth of the economy itself, this nurtured a vast increase in government personnel along with a uniquely bureaucratic ethos. And because parliament had to approve taxes, the crown's chronic need for military finance in the seventeenth and eighteenth centuries contributed directly to parliamentary supremacy. The shift in the seventeenth century from royal to public finances, from shortterm royal borrowing to handle exigencies to the creation of a permanent national debt, and Parliament's accompanying control over taxation and audit, were central to these transformations, with major implications for the concept of citizenship. ${ }^{62}$ In sum, by allowing the bureaucracy and Parliament to displace the royal court as the locus of power, commercial-military dynamics recast national institutions at the same time as the struggle against French "popery and tyranny" blended Protestant virtue, British liberties, and shared island-hood. Myanmar offers parallels to many of these

\footnotetext{
${ }^{60}$ Kathy Lavezzo, Angels on the Edge of the World: Geography, Literature, and English Community, 1000-1534 (Ithaca, 2006).

61 Lieberman, "Secular Trends"; Michael Duffy, "Contested Empires, 1756-1815," in Paul Langford, ed., The Eighteenth Century, 1688-1815 (Oxford, 2002), 239.

${ }^{6}$ John Brewer, The Sinews of Power: War, Money, and the English State, 1688-1783 (Cambridge, Mass., 1988); Braddick, State Formation, pt. III; Langford, Polite and Commercial People, 702-10; Pincus, 1688, ch. 12.
} 
developments, but always less sustained and intense. If the British government in 1815 obtained 20 percent of national GDP, its Burmese counterpart probably never secured 10 percent of an economy that was less than a tenth as large and notably less monetized and urbanized. Opportunities for government expansion and administrative routinization were correspondingly limited.

Likewise, in Britain printing, urbanization, and unique advances in overland and maritime transport accelerated more rapidly than in Myanmar the horizontal diffusion of culture from the political core to outlying dependencies. And in vertical terms, the growing size and self-confidence of commercial strata broadened the audience for national politics. By 1770, by some definitions, in England and Wales the so-called "middling sort" had swelled to 40 percent of the population. ${ }^{63}$ Their influence appeared in the arts and in a consumer culture that encouraged a degree of social fluidity. But above all we see their influence in politics, where a public sphere grew more socially inclusive, institutionally secure, and programmatically ambitious. The physical foundation for this new politics, for an emergent civil society, was a competitive urban press joined to an urban mycelium of clubs, debating societies, and coffee houses where political affairs were freely discussed and schemes of domestic reform and national strengthening considered. Controlling some of the most dynamic sectors of the economy, businessmen, shopkeepers, and professionals now championed a participatory model of citizenship that let individuals appropriate and redefine patriotism. In the 1830 s to 1850 s spokesmen for the industrial working class broadened this approach to demand universal male suffrage and parliamentary reform. ${ }^{64}$ Political equality, not inequality, now was becoming inherently moral.

Myanmar, we saw, also knew rising literacy and cultural circulation. But while social categories in Britain grew more fluid and open, in Myanmar after 1760 the Kon-baung dynasty succeeded in strengthening hereditary service categories. Whereas in Britain subjects became citizens, in Myanmar sovereignty remained exclusively royal. I find no aspiring Burmese social groups eager to expand their influence, no urban institutions open to public discussion, no sense of public entitlement, and no commentary critical of royal institutions. The consistent ambition of courtiers, literati, and commoners alike was not to assert individual or collective rights in the face of royal restriction, but rather to find a patron whose authority derived from

63 Kathleen Wilson, The Sense of the People: Politics, Culture and Imperialism in England, 1715-1785 (Cambridge, 1998), 57; Langford, Polite and Commercial People, 61-65.

64 Neil McKendrick, John Brewer, and J. H. Plumb, eds., The Birth of a Consumer Society: The Commercialization of Eighteenth-Century England(Bloomington, 1985); Lake and Pincus, Politics of the Public Sphere; Hannah Barker, Newspapers, Politics, and English Society 1695-1855 (Harlow, UK, 2000); James Van Horn Melton, The Rise of the Public in Enlightenment Europe (Cambridge, 2001), ch. 1. 
the throne itself. The traditional religious concern to obtain salvation by accumulating good karma only intensified this orientation by channeling wealth into religious donations and by according royal power and social hierarchy, with their inherent emphasis on patron-client inequality, a karmic justification.

To be sure, in Britain, too, salvationist religion remained vital. In contrast to French secularism, in England the Enlightenment developed largely within Protestantism. Yet insofar as Protestantism and commerce favored personal expression, they promoted not only citizen empowerment, but also more individualized, less corporate understandings of personality. ${ }^{65}$ In a broader sense, vigorous consumerism, overseas discoveries, Newtonian discoveries, a peculiarly British empiricism, an increasingly scientific public culture, the search for a natural order in human relations, and a generalized fatigue with religious contention all joined to secularize society and compress religious claims and undermine the authority of sacred texts to a degree quite unknown in Southeast Asia and indeed Asia. In response to these insistent currents, Protestant scripturalism was refashioned into a more rational, private, and tolerant faith, with a post-Calvinist emphasis on God's benevolence and the pursuit of happiness in this world. To paraphrase Brad Gregory, Britons decided to eschew theology in order to go shopping. ${ }^{66}$ Popular loyalty focused on Parliament and the monarchy as guarantors of overseas empire and domestic prosperity. Thus, in Britain, unlike Myanmar, popular patriotism-nationalism-filled much of the space opened by the demands of commerce, the retreat of aristocratic privilege, and the evolution of religion.

In conclusion, much of early modern Eurasia may be conceived as consisting of three political zones - a zone ruled by Inner Asian conquest elites, a protected zone, and the zone of modern nationalism - with the third evolving from the second. A shared lineage in the latter two zones produced common features, most notably polity-defining ethnonyms, vertical ethnic unity deployed against rival polities, and a lingering, if ambiguous universalism. And yet by 1750 Europe's trajectory had diverged markedly from more common forms of political ethnicity, for it was only in this third zone that nationalism and democracy evolved.

65 Dror Wahrman, The Making of the Modern Self (New Haven, 2004).

66 Brad S. Gregory, The Unintended Reformation: How a Religious Revolution Secularized Society (Cambridge, Mass., 2012), 243. 
Abstract: Insisting on a radical divide between post-1750 ideologies in Europe and earlier political thought in both Europe and Asia, modernist scholars of nationalism have called attention, quite justifiably, to European nationalisms' unique focus on popular sovereignty, legal equality, territorial fixity, and the primacy of secular over universal religious loyalties. Yet this essay argues that nationalism also shared basic developmental and expressive features with political thought in pre-1750 Europe as well as in rimland-that is to say outlying - sectors of Asia. Polities in Western Europe and rimland Asia were all protected against Inner Asian occupation, all enjoyed relatively cohesive local geographies, and all experienced economic and social pressures to integration that were not only sustained but surprisingly synchronized throughout the second millennium. In Western Europe and rimland Asia each major state came to identify with a named ethnicity, specific artifacts became badges of inclusion, and central ethnicity expanded and grew more standardized. Using Myanmar and pre-1750 England/Britain as case studies, this essay reconstructs these centuries-long similarities in process and form between "political ethnicity," on the one hand, and modern nationalism, on the other. Finally, however, this essay explores cultural and material answers to the obvious question: if political ethnicities in Myanmar and pre-1750 England/ Britain were indeed comparable, why did the latter realm alone generate recognizable expressions of nationalism? As such, this essay both strengthens and weakens claims for European exceptionalism.

Key words: cultural integration, political ethnicity, nationalism, ethnic conflict, Eurasian comparisons, European exceptionalism, Southeast Asia, Myanmar, England, Britain 